\title{
Reproductive aspects of Dendropsophus sanborni (Anura, Hylidae) in northeastern Argentina
}

\author{
Lucila M. Curi1 ${ }^{1}$, Gabriela. B. Olea ${ }^{1}$, Blanca B. Álvarez ${ }^{1}$, Jorge A. Céspedez ${ }^{1}$ \& Daniel M. Lombardo²
}

1. Laboratorio de Herpetología, Facultad de Ciencias Exactas y Naturales y Agrimensura, Universidad Nacional del Nordeste, Av. Libertad 5470, Corrientes, Argentina. C. P. 3400.
(lucilacuri@gmail.com, gbolea@gmail.com, alvarezherpetologia1@yahoo.com.ar, cespedez2003@com.ar)
2. Cátedra de Histología y Embriología. Facultad de Ciencias Veterinarias. Universidad de Buenos Aires. Instituto de Investigación y Tecnología en Reproducción Animal (INITRA).
Chorroarin 280, Buenos Aires (CABA), Argentina. C. P. 1428. (dmlombardo@gmail.com)

\begin{abstract}
Reproductive aspects of Dendropsophus sanborni (Anura, Hylidae) in northeastern Argentina. The aim of this investigation was to characterize reproductive aspects of Dendropsophus sanborni (Schmidt, 1944) (Anura, Hylidae) in the northwest of Corrientes province, in northeastern Argentina. The reproductive cycles of males and females, the existence of sexual dimorphism and the male's vocalization period were analyzed. Samplings were made from September 2011 to August 2012. Dendropsophus sanborni showed a prolonged reproductive pattern because reproductive activity was observed during most part of the year. Calling males were recorded all months except in July. The spermatogenic cycle can be characterized as potentially continuous. In males, snout-vent length was significantly correlated with mean testicular volume. The species showed sexual dimorphism in body mass, with females larger than males. Post-ovulatory females were found from March to June and most females had oocytes at different stages of maturity, with abundant post-vitellogenic oocytes from August to December.
\end{abstract}

KEYWORDS. Reproduction, vocalizations, gonads.

RESUMEN. Aspectos reproductivos de Dendropsophus sanborni (Anura, Hylidae) en el nordeste de la Argentina. El objetivo del presente estudio fue caracterizar aspectos reproductivos de Dendropsophus sanborni (Schmidt, 1944) (Anura, Hylidae) en la región noroeste de la provincia de Corrientes, al Nordeste de Argentina. Para esto, se analizó el ciclo gonadal de machos y hembras, la existencia de dimorfismo sexual y el periodo de vocalización de los machos. Los muestreos se efectuaron desde Septiembre de 2011 hasta Agosto de 2012. Dendropsophus sanborni exhibe un patrón reproductivo prolongado, dado que la actividad reproductiva ocurre durante gran parte del año. Se registraron machos en actividad de vocalización durante todos los meses excepto en julio. El ciclo espermatogénico puede ser caracterizado como potencialmente continuo. En los machos hubo correlación significativa entre la longitud hocico-cloaca y el volumen testicular medio. La especie presentó dimorfismo sexual en relación a la masa corporal, siendo las hembras mayores que los machos. Se encontraron hembras post-ovulatorias desde Marzo a Junio y una mayor proporción de hembras con ovocitos en diferentes estados de maduración, con abundantes ovocitos post-vitelogénicos, en los meses de Agosto a Diciembre.

PALABRAS CLAVE. Reproducción, vocalizaciones, gónadas.

Anurans have a complex life cycle and show much greater diversity of reproductive modes than other groups of vertebrates (Duelman \& TRUEB, 1994). Thus, they are a very interesting taxon for reproductive biology studies. Knowledge in the reproductive biology is useful to understand the adaptations of organisms to different environments and provides information to determine the conservation status of wildlife species (BASTOS \& HADDAD, 2002). Environmental factors such as air temperature, photoperiod and rainfall determine the reproductive cycles of anurans (LOFTs, 1974). Anurans that live in tropical areas can be active throughout the year and have continuous reproductive patterns, and rainfall is the main extrinsic factor controlling their reproduction. In contrast, anurans of temperate climates are dependent on a combination of temperature and rainfall and have seasonal breeding activity (Duelman \& Trueb, 1994; Bertoluci \& Rodrigues, 2002; GotTSBERger \& GrUBer, 2004). The reproductive biology of Neotropical anurans has been widely studied in Brazil by different authors in different species such as Leptodactylus fuscus (MARAGno \& CeCHIN, 2009), Lysapsus limellus (Peralta de Almeida Prado \& Uetanabaro, 2000), Scinax fuscomarginatus (Toledo \& HadDAD, 2005), Phylomedusa azurea and Phylomedusa sauvagi
(RoDRIGUES et al., 2007). Several reproductive aspects in some northeastern Argentinean anurans have been studied in the following species: Pseudopaludicola boliviana (Duré et al., 2004), Scinax nasicus (Hamman et al., 2009), Leptodactylus chaquensis (SCHAEFER et al., 2006), Rhinella bergi (SCHAEFer \& KeHR, 2006) and Argenteohyla siemersi pederseni (CAJADE et al., 2010). However, there are few studies based on gonadal morphological analysis during the reproductive cycle. In order to increase the information about Neotropical anurans reproduction, the aim of this study was to characterize the reproduction of Dendropsophus sanborni (Anura, Hylidae) based on gonadal cycle analysis in males and females, considering the period of calling activity and the existence of sexual dimorphism. The species chosen for the present study has a snout-vent length of approximately $20 \mathrm{~mm}$, inhabits open areas, and breeds in lentic, temporary or permanent water bodies (ZARACHO et al., 2012).

\section{MATERIALS AND METHODS}

Dendropsophus sanborni individuals were collected in a private field in San Cosme (Corrientes, Argentina) $\left(27^{\circ} 25^{\prime} 42^{\prime \prime} \mathrm{S}, 58^{\circ} 37^{\prime} 59^{\prime \prime} \mathrm{W}\right)$. The site has a variety of 
typical environments of the Eastern Chaco Phytogeographic region (CABRERA, 1976). The region has a subtropical or mesothermal climate (CARNEVALLI, 1994). The annual average temperature is between $19.5^{\circ} \mathrm{C}$ and $21^{\circ} \mathrm{C}$. January is the warmest month (monthly average temperature: $27^{\circ} \mathrm{C}$ ) whereas July is the coldest (monthly average temperature: $14^{\circ} \mathrm{C}$ ). Rainfall is irregularly distributed throughout the year, with the annual minimum in winter (CARNEVALLI, 1994; BRUNIARD, 1999).

Sampling was carried monthly from September 2011 to August 2012, using the technique of surveys at breeding sites (SCOTT \& WoODWARD, 2001). Adult males and females were captured by hand between 17:00 and 22:00 hours. Air temperature and humidity were recorded during each sampling. Also, the monthly average temperature and rainfall were obtained from the Corrientes Meteorological Station located in "Dr. Pirayine Niveiro" International Airport located approximately $10 \mathrm{~km}$ to the sampling site (Fig. 1). Following capture, animals were transported to the laboratory and euthanized following the protocol established in the Animal Euthanasia Guide proposed by the Institutional Animal Care and Use Committee (IACUC) and fixed in Bouin's solution.

Morphological analysis of the genital system. All individuals were measured from the snout to the cloaca (snout-vent length: SVL) using a digital caliper (accuracy $0.01 \mathrm{~mm}$ ) and weighed with a digital scale (accuracy $0.1 \mathrm{~g}$ ). Specimens were dissected through a ventral median incision and reproductive organs were exposed for analysis and documentation. To estimate males' testicular volume, we used the length and width of the right testis as parameters for spheroid formula (Dunham, 1983). In females, the criteria used to classify the oocytes were according to Valdez-Toledo \& Pisanó (1980): pre-vitellogenic oocytes are translucent, without yolk accumulation in the cytoplasm; oocytes in primary vitellogenesis have an opaque and milky aspect due to yolk accumulation; and post-vitellogenic oocytes are higher than the previous ones, with differentiated animal and vegetal poles. The presence of post-ovulatory bodies, atretic follicles and the state of the oviduct were also analyzed. Females with post-vitellogenic oocytes were considered mature.

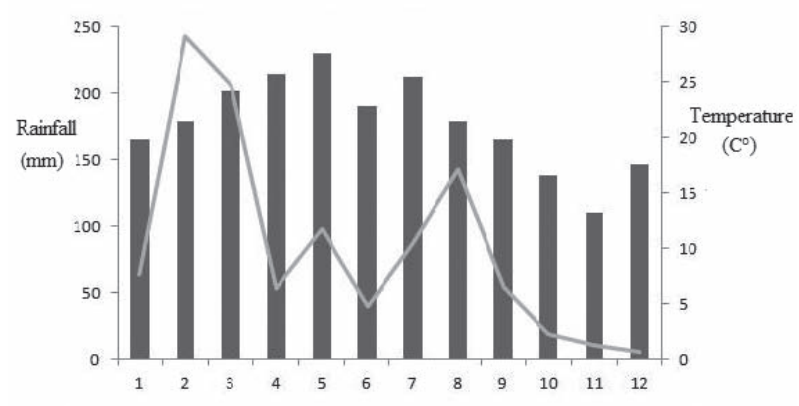

Fig. 1. Monthly average rainfall (mm) (bars) and monthly average temperature $\left(\mathrm{C}^{\circ}\right)$ (lines) from September 2011 to August 2012 in San Cosme (Corrientes, Argentina).
Histological analysis of the reproductive system. For histological analysis, gonads of males and females were dehydrated and embedded in paraffin. Sections of 5 - 7 microns were obtained with a Spencer manual rotary microtome for subsequent coloration with hematoxylin and eosin. The specimens were deposited in the herpetological collection of the Universidad Nacional del Nordeste (UNNE), Corrientes, Argentina.

Statistical analysis. For males, a linear regression was performed between SVL/individual mass, SVL/testis length, SVL/average testicular volume, body mass/testes length. Correlation was also evaluated between temperature and precipitation and abundance of mature males and females. Sexual dimorphism in size (SVL and mass) was evaluated by Student's t test and an ANCOVA was used to test differences in testicular volume in all periods, using SVL as covariate. The statistical tests were performed using the software Past Version v1.99 (HAMMER et al., 2001) and INFOSTAT Versión 2009 (www.Infostat.com. ar) (InfoStat, 2009).

\section{RESULTS}

Males. Calling males were recorded in all months except July. Vocalization activity begins just before sunset and continues throughout the night. The testicles are smooth, oval, with whitish bodies located in the abdominal region, ventral to the kidneys. The mean testicular volume was $0.27 \mathrm{~mm}^{3}$ and the highest values of adjusted testicular volume (ATV) were from September to February (Fig. 2). The ANCOVA not show significative differences between the ATV along the months $(\mathrm{F}=1.82, p=0.155, \mathrm{n}=24)$. The SVL of males ranged from 12.35 to $19.36 \mathrm{~mm}(\mathrm{x}=15.83$, $\mathrm{n}=32$ ) and the mass ranged between 0.13 and $0.39 \mathrm{~g}(\mathrm{x}$ $=0.22, \mathrm{n}=32$ ). There was a positive relation between the SVL and testicular volume $(\mathrm{R} 2=0.40, p=0.0006, \mathrm{n}=24)$ (Fig. 3). There was no relation between SVL and male's body mass ( $\mathrm{R} 2=0.06, p=0.18, \mathrm{n}=24)$, SVL and testes length ( $\mathrm{R} 2=0.08, p=0.18, \mathrm{n}=24$ ), testes length and individual mass ( $\mathrm{R} 2=0.05, p=0.30, \mathrm{n}=24$ ), or between the number of mature males recorded and the monthly average temperature $\left(\mathrm{R}^{2}=0.02, p=0.69, \mathrm{n}=24\right)$ and with the monthly mean rainfall $\left(\mathrm{R}^{2}=0.00, p=0.85, \mathrm{n}=24\right)$. Histologically, spermatogenesis occurs in the seminiferous tubules. All the cells are organized as cysts, which are supported by a large number of Sertoli cells. Each cyst contains cells at the same stage of development. The seminiferous tubules contained: spermatogonia, spermatocytes, spermatids in differentiation and spermatozoa. The cell types and the proportion varied over the months. In autumn and winter, there was a higher proportion of spermatogonia and primary spermatocytes and a lower proportion of spermatids and spermatozoa (Figs 4, 5). In spring (Figs 6,7 ) and summer (Figs 8, 9), active spermatogenesis was observed in all the seminiferous tubules. A large number of primary spermatocytes, spermatids in differentiation 


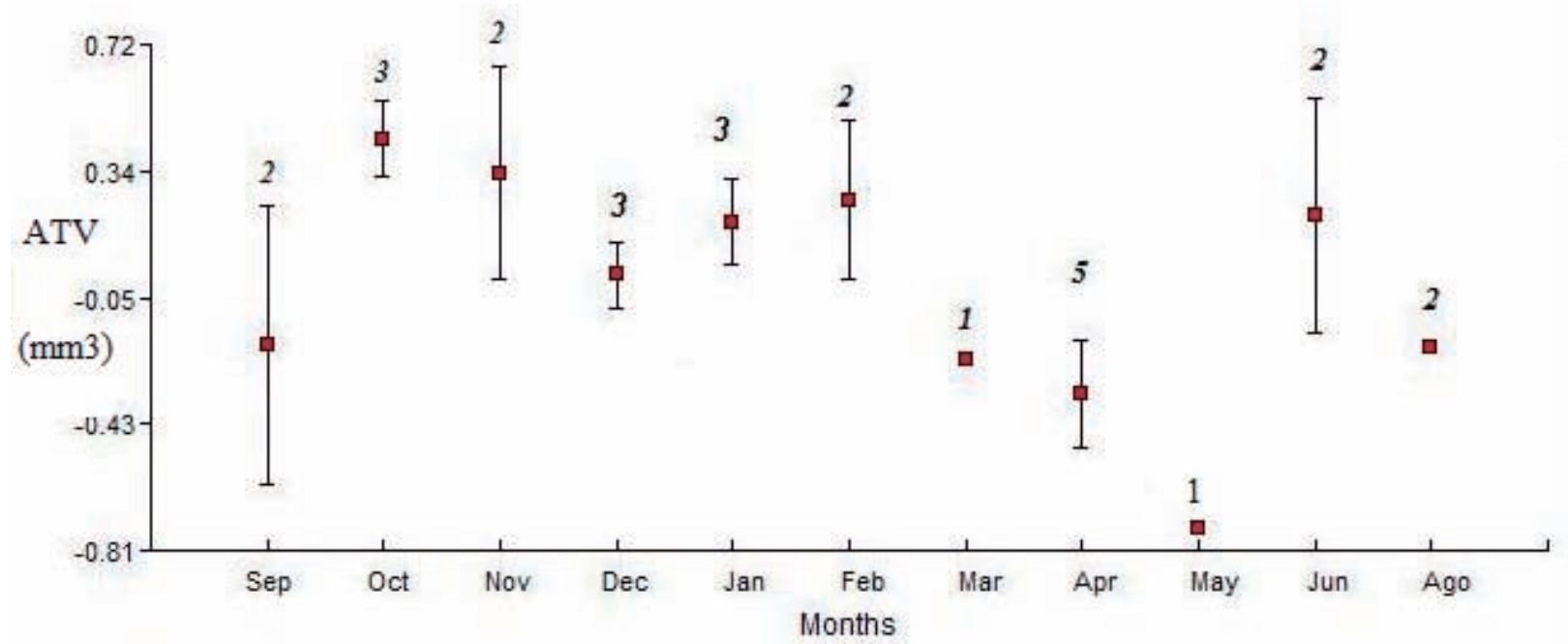

Fig. 2. Variation in testicular volume of Dendropsophus sanborni males from September 2011 to August 2012 in San Cosme (Corrientes, Argentina) (", Mean; $\$$, Mean \pm SE).



Fig. 3. Linear regression between snout-vent length (SVL) and right testicular volume (RTV) in San Cosme (Corrientes, Argentina). ( $p=0.0006, \mathrm{n}=24)$.

and free spermatozoa were observed in the lumen of the seminiferous tubules or bound to Sertoli cells. During the summer, most of the seminiferous tubules had free spermatozoa (Figs 8, 9).

Females. The SVL of females ranged between 14.36 and $19.91 \mathrm{~mm}(\mathrm{x}=17.42, \mathrm{n}=15)$ and mass between 0.14 and $0.50 \mathrm{~g}(\mathrm{x}=0.27, \mathrm{n}=15)$. The body mass of females was significantly higher than the body mass of males $(\mathrm{t}=1.15 p<0.05)$, but no significant difference was observed in the SVL $(t=3.29 p>0.05)$. The ovaries are paired, multilobulated structures surrounded by a thin tunic albuginea which reveals oocytes at different stages of maturation. The pre-vitellogenic oocytes are small, whitish and translucent, the vitellogenic oocytes have a medium size and a brownish color due to the accumulation of yolk, and the post-vitellogenic oocytes have a dark color in the animal pole and a white color in the vegetal pole. The ovary composition showed changes during the reproductive cycle. From March to June, all females showed recent ovulation evidence and the ovary had abundant postovulatory bodies and a convoluted oviduct (Figs 10,11). From August to December, females had oocytes at different stages of maturation. The post-vitellogenic oocytes were very abundant and occupied most of the ovary, whereas the pre-vitellogenic oocytes were less abundant. This could represent that females were ready to ovulate (Figs 12, 13). Histologically, ovogonia and pre-vitellogenic oocytes were observed in the periphery and vitellogenic and postvitellogenic oocytes were observed in the medullar region of the ovary (Fig. 13).

\section{DISCUSSION}

Spermatogenesis is regulated by an interaction between endogenous and environmental factors (PANIAGUA et al., 1990). According to LofTs (1974), the temperature, 

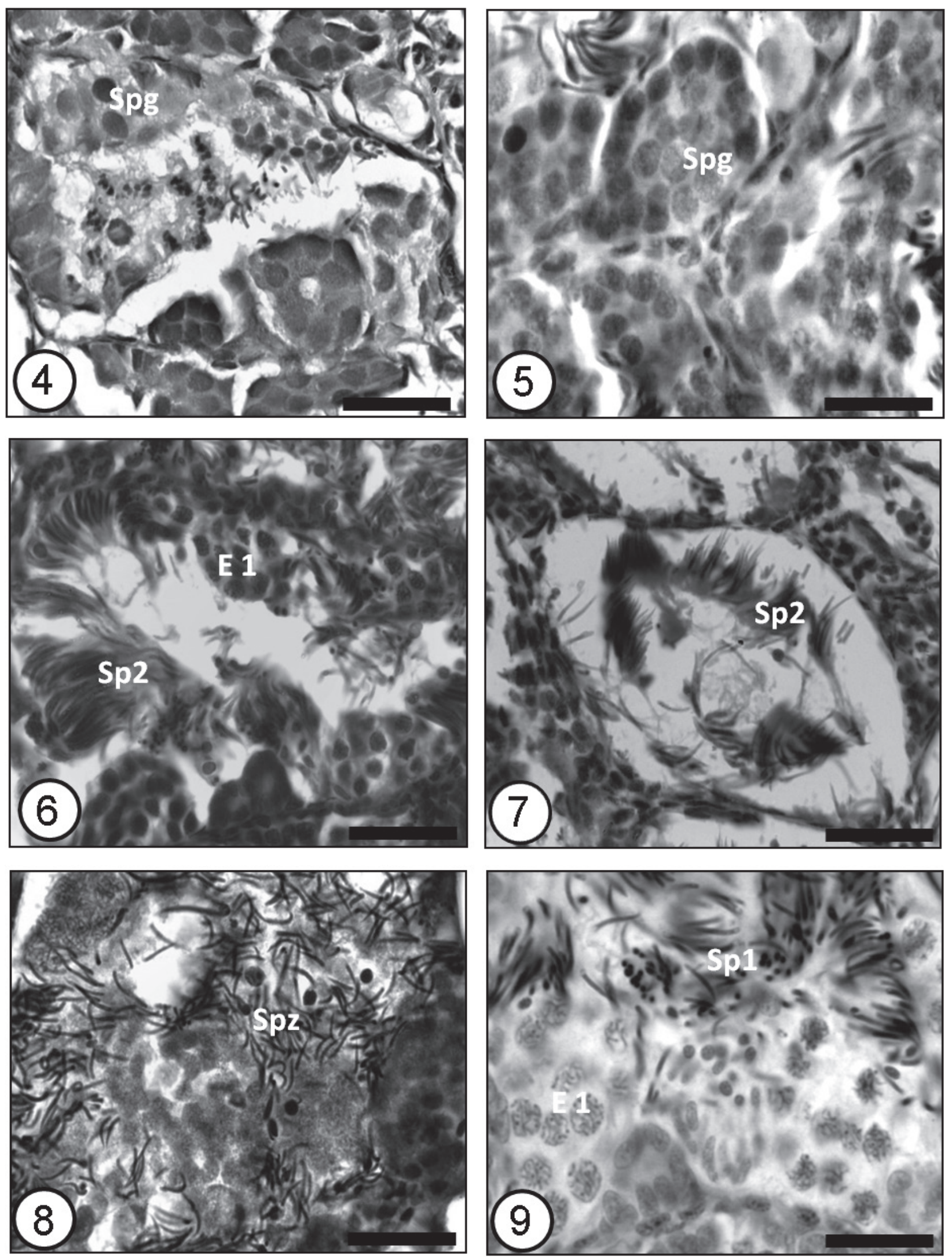

Figs 4-9. Histological sections of $D$. sanborni testes corresponding to autumn (4), winter (5), spring (6, 7), summer (8, 9) (100x) (Spg, Spermatogonia; E1, Primary spermatocytes; Sp1, Early Spermatids; Sp2, Late Spermatids; Spz, Free spermatozoa). Scale, $20 \mu \mathrm{m}$. 

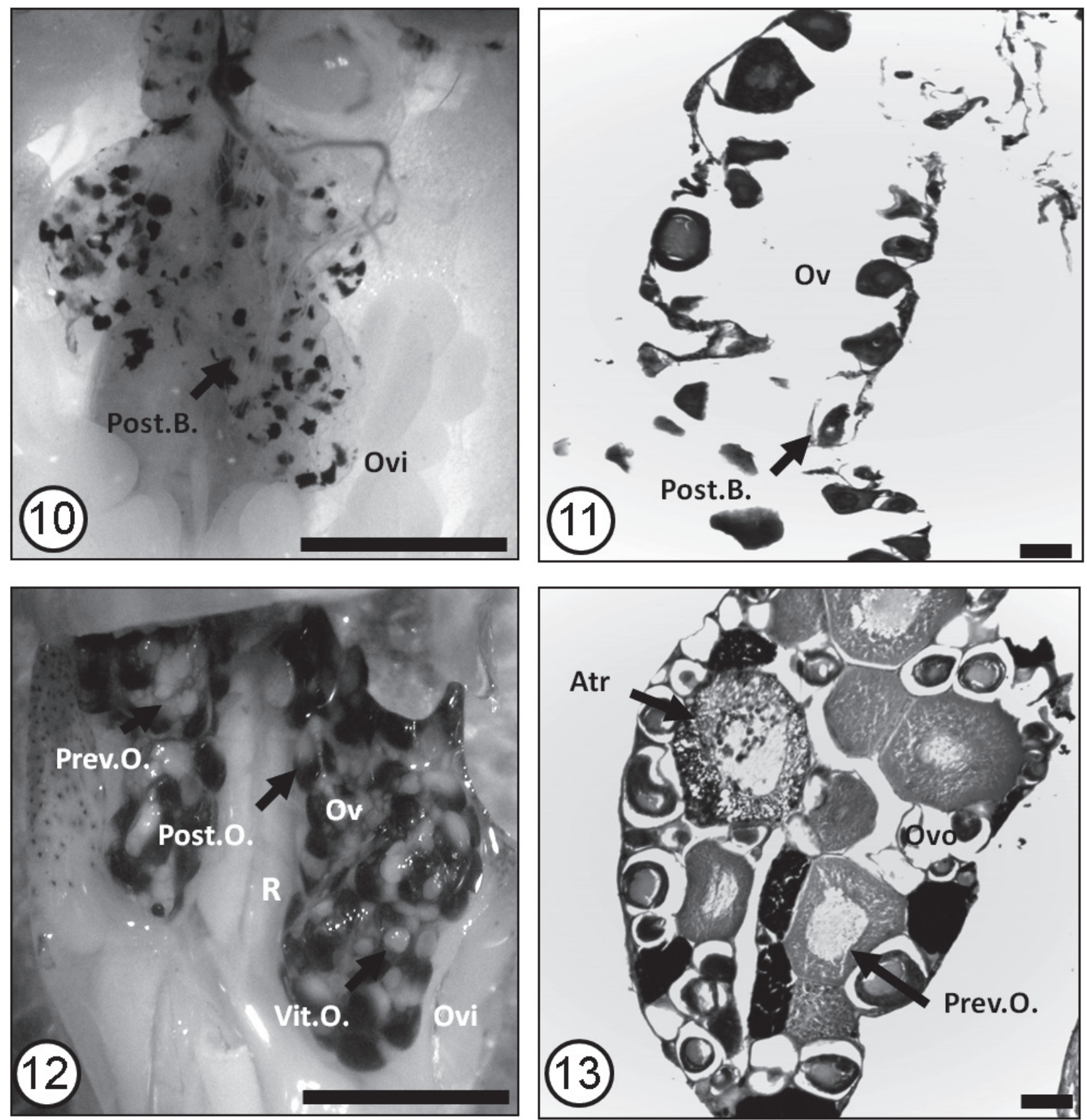

Figs 10-13. Macroscopic (10) and microscopic (11) view of D. sanborni post-ovulatory ovary (40x); macroscopic (12) and microscopic (13) view of gravid females (40x) (Prev.O, Pre-vitellogenic oocytes; Vit.O., Vitellogenic oocytes; Post.O., Post-vitellogenic oocytes; Post.B., Post-ovulatory body; Atr, Atretic oocytes; Ov, Ovary; Ovo, Ovogonia; Ovi, Oviduct). Scale, $20 \mu \mathrm{m}$.

rainfall and photoperiod are the main environmental factors involved in the regulation of the reproductive cycle of frogs. The spermatogenic cycle can be classified as potentially continuous, characterized by gonadal quiescence in certain periods of the year, but spermatogonia remains sensitive to gonadotropin stimulation (HuANG et al., 1997). Our results reveal that, in Dendropsophus sanborni, spermatogenesis shows peaks of activity in spring and summer and reduced activity in autumn and winter. Although no statistically significant differences were recorded in testicular volume in all months, we observed the highest values in spring and summer. In São Paulo (Brazil), SANTos \& Oliveira (2007) revealed a continuous cycle for males of the co-generic species Dendropsophus minutus. This type of cycle is characteristic of species from tropical climates where the weather conditions do not show appreciable fluctuations along the year. MARAGNO \& CECHIN (2009) found a positive correlation between the number of mature individuals and the monthly average temperature in a Leptodactylus fuscus population in Rio Grande do Sul (Brazil), a place with subtropical climate. In our analysis, neither the correlation with temperature nor that with monthly average rainfall was statistically significant. However, it is expected and has been observed that temperature plays a fundamental 
role in the reproduction in frogs of subtropical climates (Duellman \& Trueb, 1994).

Spermatogenesis in D. sanborni is similar to that described in other frogs (Hermosilla et al., 1983; OLIVEIRA et al., 2002, 2003). Spermatocytes are usually observed in the prophase of the first meiotic division, with different levels of chromosome condensation. At the end of spermatogenesis, spermatozoa remain together in bundles supported by the Sertoli cells. They are then released into the lumen of the seminiferous tubule where they remain until they are released.

The ovary exhibits the same structural pattern as the rest of anurans. It has a central cavity, covered by a thin colorless coat which reveals the oocytes for transparency (De Souza Santos \& De Oliveira, 2007). Morphological analysis revealed different cell types: oogonia, previtellogenic, vitellogenic and post-vitellogenic oocytes. The ovaries showed large morphological changes during the reproductive cycle. The presence of post-vitellogenic oocytes throughout most of the study period indicates that females may be ready to oviposit all the time, and do it when the environmental conditions are favorable. MARTORI et al. (2005) indicated that the reproductive activity in Elachistocleis bicolor and Leptodactylus latinasus females is concentrated in spring and summer, but during this season the females can oviposit several times. In the present study, some pre-vitellogenic and vitellogenic oocytes were observed in atresia. This process is common in the ovaries of frogs, because during ovulation, not all follicles get to spend the oviduct (PuCHi Alcaide et al., 2012). According to SHINe (1979), females have larger body size than conspecific males in $90 \%$ of frogs. A larger size gives a high fecundity to females (Salthe \& Duellman, 1973; Crump, 1974). In the present study, the females were significantly larger than males in body mass, similar to that observed in Rhinella arenarum (Quiroga et al., 2004) and Elachistocleis bicolor (RODRIGUEs et al., 2003). Differently, in Scinax nasicus, which frequently co-occurs with $D$. sanborni, no sexual dimorphism has been found (Hamman et al., 2009). According to Wells (1977), it can be considered that $D$. sanborni has a prolonged breeding because the species breeds for three months or more. The extended period of vocalization of males and the presence of mature females during most of the year would indicate a prolonged reproductive period for this frog. In our study, rainfall varied significantly throughout the year, and the dry season coincided with the winter months. However, the mean temperatures did not show large variations. This could explain the presence of calling males vocalizing during all the study, except in July, when the temperatures were very low (monthly average temperature: $13.5^{\circ} \mathrm{C}$ ). However, considering that Dendropsophus nanus, a very close and sympatric congener of $D$. sanborni, has a continuous reproductive pattern in the Pantanal of Brazil (PRADO et al., 2005), where reproduction occurs throughout the year and is positively correlated with rainfall and temperature, we cannot rule out a potential continuous reproductive activity for $D$. sanborni in northeastern Argentina. These data suggest that the species may present different patterns depending on the climate under which they live and that this plasticity should be evaluated considering determinant factors, such as rainfall, temperature, photoperiod, or a combination of them.

Acknowledgements. We thank Susana Soto for providing the climate data of the Meteorological Station Corrientes. This work was supported by grants 2011-2014 Scientific Programming, UNNE: SGCYT - UNNE F020 and SGCyT- UNNE 12F008.

\section{REFERENCES}

Bastos, R. P. \& Haddad, C. F. B. 2002. Acoustic and aggressive interactions in Scinax rizibilis (Anura: Hylidae) during reproductive activity in southeastern Brazil. Amphibia-Reptilia 23:97-104.

BerTOLUCI, J. \& Rodrigues, M. T. 2002. Utilização de habitats reprodutivos e micro-habitats de vocalização em uma taxocenose de anuros (Amphibia) da Mata Atlântica do sudeste do Brasil. Papéis Avulsos de Zoologia 42(11):287-297.

BRUNIARD, E. 1999. Los regímenes hídricos de las formaciones vegetales. Aportes para un modelo foto climático mundial. Resistencia, EUDENE. 382p.

Cabrera, A. L. 1976. Regiones Fitogeográficas Argentinas. In: Enciclopedia Argentina de Agricultura y Jardinería. 2ed. Buenos Aires, Editorial ACME, p. 18-25.

Cajade, R.; Schaefer, E. F.; Duré, M.I; Kehr, A. I. \& Marangoni, F. 2010. Reproductive biology of Argenteohyla siemersi pederseni Williams and Bosso, 1994 (Anura: Hylidae) in northeastern Argentina. Journal of Natural History 44(29/32):1953-1978.

Carnevalli, R. 1994. Fitogeografía de la provincia de Corrientes. Corrientes, Gobierno de la Provincia de Corrientes y Instituto Nacional de Tecnología Agropecuaria. 324p.

Crump, M. L. 1974. Reproductive strategies in a tropical anuran community. Miscelaneous Publications, Museum of Natural History 61:1-68.

De Souza Santos, L. R. \& De Oliveira, C. 2007. Morfometria testicular durante o ciclo reprodutivo de Dendropsophus minutus Peters Anura, Hylidae. Revista Brasilera de Zoologia 24(1):64-70.

Duellman, W. E. \& Trueb, L. 1994. Biology of amphibians. Baltimore, The Johns Hopkins University Press. 670p.

Dunham, A. E. 1983. Realized niche overlap, resource abundance and intensity of interespecific competition. In: Huey, R.B.; PianKa, E. R. \&. Schoener, T. W. eds. Lizzard Ecology. Cambridge, Harvard University Press, p. 261-280.

Duré, I. M.; Schaefer, E. F.; Hamman, M. I. \& Kehr, A. I. 2004. Consideraciones ecológicas sobre la dieta, reproducción y parasitismo de Pseudopaludicola boliviana (Anura, Leptodactylidae) de Corrientes, Argentina. Phyllomedusa 3(2):121-131.

GotTsBerger, B. \& Gruber, E. 2004. Temporal partitioning of reproductive activity in a neotropical anuran community. Journal of Tropical Ecology 20:271-280.

Hamman, M. I.; Kehr, A.; GonzÁles, C. E; Duré, M. \& Schaefer, E. 2009. Parasite and reproductive features of Scinax nasicus (Anura: Hylidae) from South American Subtropical area. Interciencia 34(3):214-218.

Hammer, Ø.; Harper, D. A. T. \& Ryan, P. D. 2001. PAST: PAleontological STatistic software package for education and data analysis. Available at <http://folk.uio.no/ohammer/past>. Accessed on December 2013.

Hermosilla, I. B.; Urbina, A. P. \& Cabrera, L. P. 1983. Spermatogenesis in the chilean frog Caudiverbera caudiverbera (Linne, 1758) (Anura, Leptodactylidae). Boletin de la Sociedad de Biologia de Concepción 54:103-115.

Huang, W. S.; Lin, J. Y. \& Yu, J. I. L. 1997. Male reproductive of the toad Bufo melanostictus in Taiwan. Canadian Journal of Research, Zoological Sciences 14:497-503.

InFoStAT. 2009. InfoStat Versión 2009. Grupo InfoStat, FCA, Universidad Nacional de Córdoba, Argentina. 
Lofts, B. 1974. Reproduction. In: LofTs, B. ed. Physiology of the Amphibians. New York, Academic Press, p. 107-218.

Maragno, F. P. \& Cechin, S. Z. 2009. Reproductive Biology of Leptodactylus fuscus (Anura, Leptodactylidae) in the subtropical climate, Rio Grande do Sul, Brazil. Iheringia, Série Zoologia 99(3):237-241.

Martori, R.; Aun, L.; Birri, A.; Rozzi Giménez, C. \& Heredia, E. 2005. Reproducción comparada de tres especies de anuros sintópicos de una localidad del Sudeste de Córdoba. Cuadernos de Herpetología 18(2):43-59.

Oliveira, C.; Vicentini, C. A. \& Taboga, S. R. 2003. Structural characterization of nuclear phenotypes during Scinax fuscovarious spermatogenesis (Anura, Hylidae). Caryologia 56:75-83.

Oliveira, C.; ZANETONI, C. \& Zieri, R. 2002. Morphological observations on the testes of Physalaemus cuvieri (Amphibia, Anura). Revista Chilena de Anatomía 20:263-268.

Paniagua, R.; Fraile, B. \& SÁenz, F. J. 1990. Effects of photoperiod and temperature on testicular function in amphibians. Histology and Histopathology 5:365-378.

Peralta de Almeida Prado, C. \& Uetanabaro, M. 2000. Reproductive Biology of Lysapsus Limellus Cope, 1862 (Anura, Pseudidae) in the Pantanal, Brazil. Zoocriaderos 3:25-30.

Prado, C. P. A.; Uetanabaro, M. \& Haddad, C. F. B. 2005. Breeding activity patterns, reproductive modes, and habitat use by anurans (Amphibia) in a seasonal environment in the Pantanal, Brazil. Amphibia-Reptilia 26:211-221.

Pucci Alcaide, A.; Ponssa, M. L.; Pucci Alcaide, F. J. \& Alcaide, M. F. 2012. Histología de ovario en hembras de Leptodactylus latinasus (Anura: Hylidae). Acta Zoológica Lilloana 58(1-2):44-53.

Quiroga, L. B.; Sanabria, E. A. \& Acosta, J. C. 2004. Dimorfismo sexual en una población de Bufo arenarum (Anura: Bufonidae) en los humedales de Zonda, San Juan, Argentina. Boletín de la Sociedad Herpetológica Mexicana 12:37-42.

Rodrigues, D.; Lopez, S. F. \& Uetanabaro, M. 2003. Padrão reprodutivo de Elachistocleis bicolor (Anura, Microhylidae) na Serra da Bodoquena, Mato Grosso do Sul, Brasil. Iheringia, Série Zoologia 93(4):365-371.
Rodrigues, D. J.; Uetanabaro, M. \& Lopes, F. S. 2007. Breeding biology of Phyllomedusa azurea Cope, 1862 and P. sauvagii Boulenger, 1882 (Anura) from the Cerrado, Central Brazil. Journal of Natural History 41(29-32):1841-1851.

Santos, L. R .S. \& Oliveira, C. 2007. Morfometría testicular durante o ciclo reproductivo de Dendropsophus minutus (Peters) (Anura: Hylidae). Revista Brasilera de Zoologia 24(1):64-70.

Salthe, S. N. \& Duellman, W. E. 1973. Quantitative constraints associated with reproductive mode in anurans. In: VIAL, J. L. ed. Evolutionary biology of the anurans. Columbia, University of Missouri Press, p. 229-249.

Schaefer, E. F.; Hamman, M. I.; Kehr, A. I.; Gonzáles, C. E. \& Duré, M. I. 2006. Trophic, reproductive and parasitological aspects of the ecology of Leptodactylus chaquensis (Anura: Leptodactylidae) in Argentina. Herpetological Journal 16:387-394.

Schaefer, E. F. \& Kehr, A. I. 2006. Bufo bergi (NCN) Reproduction. Herpetological Review 37(3):334.

Scott, N. J. \& Woodward, B. D. 2001. Relevamientos de lugares de reproducción. In: Heyer, W. R.; Donelly, M. A.; McDiarmid, R. W.; HAYeK C. \& Foster, M. S. eds. Medición y Monitoreo de la Diversidad Biológica. Métodos estandarizados para Anfibios. Chubut, Ed. Univ. Patagonia, p. 113-120.

SHINE, R. 1979. Sexual selection and sexual dimorphism in the Amphibia. Copeia 1979:297-306.

Toledo, L. F. \& Haddad, C. F. B. 2005. Reproductive biology of Scinax fuscomarginatus (Anura, Hylidae) in south-eastern Brazil. Journal of Natural History 39(32):3029-3037.

Valdéz-Toledo, C. L. \& Pisanó, A. 1980. Fases oogenéticas en Bufo arenarum. Reproducción 4:315-330.

Wells, K. D. 1977. The courtship of frogs. In: TAYLOR, D. H. \& GutTMAn, S. I. eds. The reproductive biology of amphibians. New York, Plenum Press, p. 233-262.

Zaracho, V. H.; Céspedez, J. A.; Álvarez, B. B. \& Lavilla, E. O. 2012. Guía de campo para la identificación de anfibios de Corrientes (Arg.). Fundación Miguel Lillo/ Universidad Nacional del Nordeste. 182p. 